IJEYE_26_3 Editorial

\title{
Value/s in Early Childhood Education
}

\author{
Jane Murray \\ University of Northampton, Northampton, England \\ E-mail:IJEYE@northampton.ac.uk
}

Twenty years ago, as an early childhood teacher, I was fortunate to attend a professional development day conference led by the inimitable Professor Tina Bruce. At the conference, Tina asked we early childhood teachers: 'What one thing would you put your back to the wall for in your job?' In other words, Tina wanted us to share with one another the values that guide our daily work with young children and their families. An avowed Froebelian, Tina herself subscribes to a very particular set of values (Bruce, 2015) and she is not alone. Many early childhood educators over two centuries have been influenced by the principles and philosophy developed by Froebel, the original kindergarten practitioner (Froebel Trust, 2018). Indeed, as for so many others, my own initial teacher education was strongly influenced by Froebelian principles which have continued to guide my work in the field for thirty-five years. We live in an era of unprecedented global focus on early childhood development (UNESCO, 2017; WHO, 2018); in this editorial I revisit Froebel's principles and I argue that we can continue to regard them as relevant and valuable touchstones for early childhood education in the $21^{\text {st }}$ century.

Froebel believed strongly that childhood is an important phase per se rather than a preparation stage on the path to adulthood, a position reinforced by Qvortrup's allusion to children as '...human beings, not only "human becomings"' $(1994,18)$. This principle may have emerged from Froebel's own observations that young children tend to focus on the 'here and now' (Graue and Walsh 1995). However, the international early childhood policy zeitgeist is dominated by the narrative of investment return (Heckman, 2017; World Bank, 2018), which tends to subordinate values that are authentically concerned with ethics of care (Fisher and Tronto, 1990) to value for money. We ignore children's current needs and interests at our peril and at theirs, given that we cannot be certain what the future holds: as Postman (1994) notes, 'Children are the living messages we send to a time we will not see' (p.xi).

A second Froebel principle highlights the importance of relationships between each child and his or her environment, including family, community, culture and society: an idea that Bronfenbrenner (1979) also modelled in his ecological systems theory. Worldwide, increasing numbers of young children now spend long days in settings outside their family homes, so the connections they develop with practitioners in early childhood settings, alongside positive parent-practitioner partnerships, strongly influence their development (Elfer, Greenfield, Robson, Wilson, \& Zachariou, 2018; Murray, Teszenyi, Nagy Varga, Pálfi, Tajiyeva, \& Iskakova, 2018). In his children's garden - or kindergarten Froebel extended his principle of each child's relationship with the environment to include nature. More recently, Louv (2005) has recognised the importance of biophilia for young children's optimal development and well-being, yet recent decades have witnessed a reduction in children experiencing nature outdoors (Bento and Dias, 2017).

Froebel valued each child's unique capacity and potential as a third principle. In more contemporary discourse, this idea has been promoted by 'new' sociologists, who regard even the youngest children as competent social agents (James, Jenks and Prout, 1998), a concept that has informed global policy (OHCHR, 2005). Nevertheless, children's rights legislation has not yet moved beyond the notion of young children's 'evolving capacities' (Lansdown, 2005, ix). 
Froebel's fourth principle identifies that each child develops best when given opportunities to do so holistically: as Ball (1994) notes in the UK Start Right report, young children develop '...emotionally, intellectually, morally, socially, physically and spiritually. All are important; each is interwoven with others' (p.53). In 2001, the OECD agreed that high quality early years policy should include 'pedagogical frameworks focusing on children's holistic development', yet less than two decades later, driven by economic imperatives, OECD (2018) now defines high quality for early childhood more narrowly, emphasising 'cognitive and social and emotional development' to the exclusion of other areas of young children's development (Moss et al., 2016).

Froebel highlighted play and creativity as vital cross-cutting aspects of young children's development and learning as his fifth principle. He regarded play as '... the highest expression of human development in childhood for it alone is the free expression of what is in the child's soul' (Froebel, 1826, trans. 1912, 50-51). Across the world, whilst play is often recognised as valuable for learning, terms such as 'play-based learning' or 'planned, purposeful play' have emerged in early childhood curriculum frameworks (e.g. Australian Government Department of Education, Employment and Workplace Relations for the Council of Australian Governments, 2009, 5; Department for Children, Schools and Families, 2008, 11) indicating that adults who work with children should control their play. However, such a model detracts from the great value of authentic play that Froebel understood, which includes the mastery and autonomy that young children derive when they initiate, create and lead play for themselves.

A sixth principle that Froebel espoused was that adults should ensure children's well-being and protect them from harm. Child protection and well-being have been prominent in UNICEF's work (UNICEF, 2017; UNICEF IRC, 2007), although well-being remains a concept for which a clear, simple definition has been slow to emerge (Forgeard, Jayawickreme, Kern, \& Seligman, 2011). Recently, global attention has turned to an idea of 'nurturing care', which

'...refers to conditions created by public policies, programmes and services. These conditions enable communities and caregivers to ensure children's good health and nutrition, and protect them from threats. Nurturing care also means giving young children opportunities for early learning, through interactions that are responsive and emotionally supportive'

(WHO, 2018, 2).

This nurturing care model affords an integrated, holistic approach to education and care that aligns well with Froebel's philosophy.

Within the scope of this short editorial, it has only been possible to touch briefly on a few ways that contemporary young children may continue to experience Froebel's principles. In my work as an Editor, I often read in articles that are submitted for the International Journal of Early Years Education that reveal those principles continuing to penetrate practice, research and discourse in the field of early childhood. This issue comprises seven such articles: each exemplifies Froebel's principles in some way.

The first article in this issue is a review from Katarina Filipović and Nóirín Hayes which resonates with Froebel's first principle that childhood itself is important, rather than a time to prepare children for later stages in their lives. In "Nurturing "buds of development": from outcomes to opportunities in early childhood practice', Filipović and Hayes contest the 'current future-focused, outcomes driven early childhood policy climate' by synthesising the capabilities approach with a bio-ecological model as a basis for an argument for change. The two articles that follow reflect themes from Froebel's second principle concerning relationships between each child and his or her environment, featuring family, community, culture, society or nature. Jennifer Masters' and Leanne Grogan's contribution, 'A comparative analysis of nature kindergarten programs in Australia and New Zealand', reports findings from an investigation of practice in seven nature kindergarten programs. Masters and Grogan 
adopted an 'immersive interview' technique comprising participant observations and semi-structured interviews and identified a range of similarities and differences between the programs concerning nature pedagogy. Findings presented in the next article by Jamal Ahmad also have an association with Froebel's principle concerned with the child's relationship with his or her environment. 'Children's drawings in different cultures: an analysis of five-year-old Jordanian children's drawings' reports a study for which the drawings of 736 children were analysed to identify how culture influenced what the children drew. Prominent themes in the research data include nature and combinations of Arabic and English numbers.

Jane Merewether's article 'Listening to Young Children Outdoors with Pedagogical Documentation' aligns with Froebel's third principal that we should recognise each child's unique capacity and potential. She reports findings from a bricolage study conducted in an early years' centre and uses evidence from the study to argue that pedagogical documentation can enable children and adults to work in synergy with their environment whilst affording adults new ways to listen to young children. In their article 'Infants' experience with "near and clear" educator talk: Individual variation and its relationship to indicators of quality', Degotardi, Han and Torr share findings from their research concerned with ways that interactions between educators and babies may support the babies' development across all areas, linking to Froebel's principle concerned with every child's holistic development.

A connection is evident between Froebel's principle that creativity and play are crucial aspects of young children's learning and development and the next article "We set up a small world":

Preschool teachers' involvement in children's imaginative play', authored by Anamika Devi, Marilyn Fleer and Liang Li. Working within a social constructivist theoretical framework, Devi et al. used observations and interviews to explore teachers' engagements in young children's play. The final article in this issue is concerned with positive ways that touch may promote and protect young children's well-being. In their article 'Adult-initiated touch and its functions at a Swedish preschool: Controlling, affectionate, assisting and educative haptic conduct', Disa Bergnehr and Asta Cekaite report findings from a qualitative study which addresses issues relating to Froebel's sixth principle that children have rights to well-being and protection from abuse and harm.

In recent decades, policymakers' concerns with economic imperatives have led to intense focus on the potential for early childhood development to provide value for money in the form of investment return. However, as the articles in this issue reveal, many who practise and research in the field of early childhood understand that values matter in work with young children and their families. Indeed, the United Nations recognised recently that in isolation, economic development is inadequate for securing a happy life, and advocated the importance of addressing social and environmental wellbeing (UNDESA, 2017). To reify this new global focus, early childhood policymakers across the world may find it useful to engage with Froebel's principles. The values that they represent are as relevant for ensuring successful early childhood education in the $21^{\text {st }}$ century as they were two centuries ago because they prioritise each child's needs and interests. When Professor Tina Bruce asked me twenty years ago, 'What one thing would you put your back to the wall for in your job?' my response was: 'Putting children's needs and interests first!' I commend to you the articles in this issue of International Journal of Early Childhood Education journal and as you read each one, I encourage you to reflect on the values that guide your work.

\section{References}

Australian Government Department of Education, Employment and Workplace Relations for the Council of Australian Governments. 2009. Belonging, Being \& Becoming - The Early Years Learning Framework for Australia. Accessed $15^{\text {th }}$ June 2018. http://files.acecqa.gov.au/files/National-QualityFramework-Resources- 
Ball, C. 1994. Start Right: The Importance of Early Learning. London: RSA.

Bento, G., \& Dias, G. 2017. 'The importance of outdoor play for young children's healthy development.' Porto Biomedical Journal, 2 (5): 157-160.

Bronfenbrenner, U. 1979. The Ecology of Human Development. Cambridge, MA: Harvard University Press.

Bruce, T. 2015. Early Childhood Education. 5e. London: Hodder Education.

Department for Children, Schools and Families (DCSF). 2008. The Early Years Foundation Stage. Annesley: Department for Children, Schools and Families.

Elfer, P., Greenfield, S., Robson, S., Wilson, D., \& Zachariou, A. 2018. 'Love, satisfaction and exhaustion in the nursery: methodological issues in evaluating the impact of Work Discussion groups in the nursery.' Early Child Development and Care, 188 (7): 892-904.

Fisher, B., \& Tronto, J. 1990. 'Toward a Feminist Theory of Caring.' In Circles of Care, edited by E. Abel \& M. Nelson. 36-54. Albany, NY: SUNY Press.

Forgeard, M. J., Jayawickreme, E., Kern, M. L., \& Seligman, M. E. 2011. 'Doing the right thing: Measuring wellbeing for public policy.' International Journal of Wellbeing 1(1).

Froebel, F. 1826, trans. 1912. Froebel's Chief Writings on Education (rendered into English). Trans. S.S.F. Fletcher \& J. Welton. London: Edward Arnold.

Froebel Trust. 2018. Froebelian Principles. Accessed: $15^{\text {th }}$ June 2018. https://www.froebel.org.uk/innovations/

Graue, M. E., \& Walsh, D. J. 1995. 'Children in Context: Interpreting the Here and Now of Children's Lives.' In Qualitative Research in Early Childhood Settings, edited by J. A. Hatch. 135-154. Westport, CT: Praeger.

Heckman, J. 2017. The Heckman Equation. Accessed: 15 th $^{\text {J }} 2018$.

https://heckmanequation.org/the-heckman-equation/

James, A., Jenks, C., \& Prout, A. 1998. Theorising Childhood. Cambridge: Polity Press.

Lansdown, G. 2005. The Evolving Capacities of Children: implications for the exercise of rights. Florence: UNICEF Innocenti Research Centre.

Louv, R. 2005. Last Child in the Woods. New York: Workman Publishing.

Moss, Peter, P., Dahlberg, G., Grieshaber, S., Mantovani, S., May, H., Pence, A., Rayna, S., Swadener, B.B., \& Vandenbroeck, M. 2016. 'The Organisation for Economic Cooperation and Development International Early Learning Study: Opening for Debate and Contestation. Contemporary Issues in Early Childhood, 17 (3): 343-351.

Murray, J., Teszenyi, E., Nagy Varga, A., Pálfi, S., Tajiyeva, M., \& Iskakova, A. 2018. 'Parentpractitioner partnerships in early childhood provision in England, Hungary and Kazakhstan: similarities and differences in discourses.' Early Child Development and Care, 188 (5): 594-612. 
OECD (Organisation for Economic Cooperation and Development). 2001. Starting Strong. Paris: OECD.

OECD (Organisation for Economic Cooperation and Development). 2018. International Early Learning and Child Well-being Study. Accessed 15 ${ }^{\text {th }}$ June 2018.

http://www.oecd.org/education/school/the-international-early-learning-and-child-well-being-studythe-study.htm

OHCHR (Office of the High Commissioner on Human Rights). 2005. Convention on the Rights of the Child: General Comment No 7. Implementing child rights in early childhood. Geneva: United Nations. Accessed: $15^{\text {th }}$ June 2018. http://www2.ohchr.org/english/bodies/crc/docs/AdvanceVersions/GeneralComment7Rev1.pdf

Postman, N. 1994. The Disappearance of Childhood. New York: Vintage.

Qvortrup, J. 1994. 'Introduction.' In Childhood Matters: Social theory, practice and politics, edited by J. Qvortrup, M. Bardy, G. Sgritta, G. \& H. Wintersberger, pp.1- Wien: Avebury.

UNDESA (United Nations Department for Economic and Social Affairs. 2017. UN connects wellbeing and the pursuit of happiness. Accessed $15^{\text {th }}$ June 2018.

http://www.un.org/en/development/desa/news/social/intl-day-happiness.html

UNESCO (United Nations Educational, Scientific and Cultural Organisation). 2017. Accessed: $15^{\text {th }}$ June 2018. http://www.unesco.org/new/en/santiago/education/early-childhood-education/

UNICEF (United Nations Children's Fund). 2017. UNICEF's Approach to Child Protection. Accessed $15^{\text {th }}$ June 2018. https://www.unicef.org/protection/57929 57990.html

UNICEF IRC (United Nations Children's Fund Innocenti Research Centre). 2007. Child poverty in perspective: An overview of child well-being in rich countries, Innocenti Report Card 7, 2007. Florence: UNICEF Innocenti Research Centre.

WHO (World Health Organisation). 2018. Nurturing Care for Early Childhood Development. Accessed: $15^{\text {th }}$ June 2018. http://www.who.int/maternal child adolescent/child/nurturing-careframework/en/

World Bank. 2018. Early Childhood Development. Accessed $15^{\text {th }}$ June 2018. http://www.worldbank.org/en/topic/earlychildhooddevelopment 